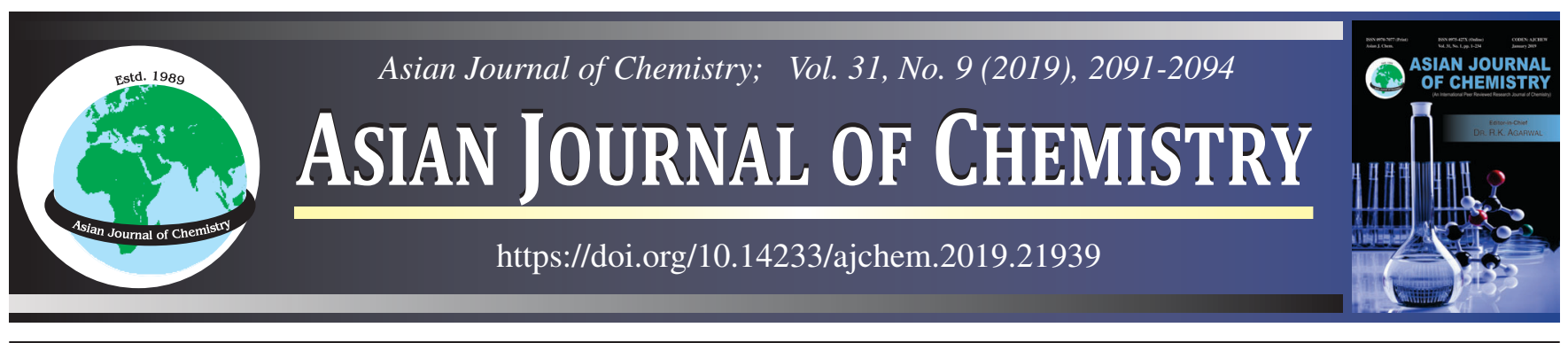

\title{
Optimization of Five Reducing Agents using UV-VIS \\ Spectrometry for Reduction of Iron(III) to Iron(II)
}

R. Djarot Sugiarso K.S. , Arum Dwi Kurnia, Dewi Ratnawati, Haryudini Arsa Putri, Herdayanto S. Putro and Ratna Ediati

Department of Chemistry, Faculty of Science, Institut Teknologi Sepuluh, Nopember Campus ITS Sukolilo, Surabaya 60111, Indonesia

*Corresponding author: E-mail: djarot@chem.its.ac.id

Received: 19 January 2019;

Accepted: 17 May 2019;

Published online: 31 July 2019;

AJC-19503

\begin{abstract}
This study aims to investigate the optimum conditions of five reducing agents viz., sodium thiosulfate $\left(\mathrm{Na}_{2} \mathrm{~S}_{2} \mathrm{O}_{3}\right)$, hydroxylamine hydrochloride $\left(\mathrm{NH}_{2} \mathrm{OH} \cdot \mathrm{HCl}\right)$, ascorbic acid $\left(\mathrm{C}_{6} \mathrm{H}_{8} \mathrm{O}_{6}\right)$, sodium oxalate $\left(\mathrm{Na}_{2} \mathrm{C}_{2} \mathrm{O}_{4}\right)$ and sodium sulfite $\left(\mathrm{Na}_{2} \mathrm{SO}_{3}\right)$ for the reduction of Fe(III) to Fe(II) using UV-Vis spectrometry. As result, the optimum $\mathrm{pH}$ of acetate buffer for $\mathrm{Na}_{2} \mathrm{~S}_{2} \mathrm{O}_{3}, \mathrm{NH}_{2} \mathrm{OH} \cdot \mathrm{HCl}_{2} \mathrm{C}_{6} \mathrm{H}_{8} \mathrm{O}_{6}, \mathrm{Na}_{2} \mathrm{C}_{2} \mathrm{O}_{4}$ and $\mathrm{Na}_{2} \mathrm{SO}_{3}$ were obtained at $\mathrm{pH} 4.5,4.5,4.5,5.0$ and 4.0, respectively. Whilst the optimum time for each $\mathrm{Na}_{2} \mathrm{~S}_{2} \mathrm{O}_{3}, \mathrm{NH}_{2} \mathrm{OH} \cdot \mathrm{HCl}_{\text {and }} \mathrm{C}_{6} \mathrm{H}_{8} \mathrm{O}_{6} \mathrm{Were} 15$ min, the outcome for $\mathrm{Na}_{2} \mathrm{C}_{2} \mathrm{O}_{4}$ and $\mathrm{Na}_{2} \mathrm{SO}_{3}$ took longer time which are 45 and 30 min, respectively. As for optimum concentration, the results were various as $\mathrm{Na}_{2} \mathrm{~S}_{2} \mathrm{O}_{3}, \mathrm{NH}_{2} \mathrm{OH} \cdot \mathrm{HCl}, \mathrm{C}_{6} \mathrm{H}_{8} \mathrm{O}_{6}, \mathrm{Na}_{2} \mathrm{C}_{2} \mathrm{O}_{4}$ and $\mathrm{Na}_{2} \mathrm{SO}_{3}$ were at 11, 7, 5, 12 and 60 ppm in consecutive order. Also to conclude the work, the recovery percentage were calculated and the results were $\mathrm{Na}_{2} \mathrm{~S}_{2} \mathrm{O}_{3}(102.81 \%), \mathrm{NH} \mathrm{H}_{2} \mathrm{OHCl} \cdot \mathrm{HCl}(116.71 \%), \mathrm{C}_{6} \mathrm{H}_{8} \mathrm{O}_{6}$ $(97.97 \%), \mathrm{Na}_{2} \mathrm{C}_{2} \mathrm{O}_{4}(85.89 \%)$, and $\mathrm{Na}_{2} \mathrm{SO}_{3}(85.04 \%)$.
\end{abstract}

Keywords: Iron, 1,10-Phenanthroline, Reducing Agents, UV-vis spectrometry.

ᄂ _ _ - - - - - - - - - - - - - - -

\section{INTRODUCTION}

The widespread use of iron has caused to increase environmental pollution, including in the ground water. The two main sources of groundwater contamination are the leakage of organic chemicals from chemical storage in underground bunker and industrial waste storage space contained by ponds or near water sources [1]. Some methods of iron analysis have been done in previous studies including atomic absorption spectrometry (AAS) [2], chromatography [3], inductively coupled plasmamass spectrometry (ICP-MS) [4], inductively coupled plasmaoptical emission spectrometry (ICP-OES) [5], sensors [6], anodic or cathodic stripping and voltammetry [7] and UV-Vis spectrometry [8]. The colorimetry method is quite affordable but their disadvantage is less sensitive than using UV-Vis spectrometry. UV-visible spectrometry has the advantage of measuring the iron in the form of ions, both $\mathrm{Fe}^{3+}$ and $\mathrm{Fe}^{2+}$. The solution was analyzed using UV-visible spectrometry, thus iron complex must be generated as coloured complex [9]. Different types of complexing agents are commonly used, such as thiocyanate acid, molybdenum, 1,10-phenanthroline, thioglycolic acid and ferrozine. However, 1,10-phenanthroline is most widely used to determine $\mathrm{Fe}^{3+}$ and $\mathrm{Fe}^{2+}$ because it is selective, direct and does not need sample extraction [10].

In this study, UV-visible spectrometry was used to determine the iron content. It started by reducing $\mathrm{Fe}^{3+}$ to $\mathrm{Fe}^{2+}$ with the addition of reducing agent. Amelia [11] examined the reducing ability of $\mathrm{Na}_{2} \mathrm{~S}_{2} \mathrm{O}_{3}$ and obtaining $\mathrm{Fe}^{2+} \%$ recovery at $99.2243 \%$. Further studies were conducted to reduce $\mathrm{Na}_{2} \mathrm{~S}_{2} \mathrm{O}_{3}$ and $\mathrm{K}_{2} \mathrm{C}_{2} \mathrm{O}_{4}$, obtained \% recovery for $\mathrm{Na}_{2} \mathrm{~S}_{2} \mathrm{O}_{3}$ was $77.93 \%$ and for $\mathrm{K}_{2} \mathrm{C}_{2} \mathrm{O}_{4}$ was $72.77 \%$ [12]. In this study, we analyzed the optimum conditions to reduce $\mathrm{Fe}^{3+}$ to $\mathrm{Fe}^{2+}$ by comparing five reducing agents are $\mathrm{Na}_{2} \mathrm{~S}_{2} \mathrm{O}_{3}, \mathrm{NH}_{2} \mathrm{OH} \cdot \mathrm{HCl}, \mathrm{C}_{6} \mathrm{H}_{8} \mathrm{O}_{6}, \mathrm{Na}_{2} \mathrm{C}_{2} \mathrm{O}_{4}$ and $\mathrm{Na}_{2} \mathrm{SO}_{3}$.

\section{EXPERIMENTAL}

The chemicals iron(III) chloride hexahydrate, 1,10phenanthroline and sodium acetate procured from Merck. Sodium thiosulfate pentahydrate, hydroxylamine hydrochloride, ascorbic acid, sodium oxalate, $99 \%$ sodium sulphite and $99 \%$ acetone are obtained from SPAM Chemical.

This is an open access journal, and articles are distributed under the terms of the Attribution 4.0 International (CC BY 4.0) License. This license lets others distribute, remix, tweak, and build upon your work, even commercially, as long as they credit the author for the original creation. You must give appropriate credit, provide a link to the license, and indicate if changes were made. 
Standard solution: The standard solution of $\mathrm{Fe}^{3+}$ was prepared by dissolving $0.0484 \mathrm{~g} \mathrm{FeCl}_{3} \cdot 6 \mathrm{H}_{2} \mathrm{O}$ in a beaker containing a small amount of deionized water. The formed solution was then poured into a $100 \mathrm{~mL}$ measuring flask and diluted.

Reducing agents solution: For reducing agent $\mathrm{Na}_{2} \mathrm{~S}_{2} \mathrm{O}_{3}$ solution is made by dissolving $0.0157 \mathrm{~g} \mathrm{Na}_{2} \mathrm{~S}_{2} \mathrm{O}_{3} \cdot 5 \mathrm{H}_{2} \mathrm{O}$ in a beaker containing a small amount of deionized water. The formed solution was then poured into a $100 \mathrm{~mL}$ measuring flask and diluted.

The reducing agent $\mathrm{NH}_{2} \mathrm{OH} \cdot \mathrm{HCl}$ solution was prepared by dissolving $0.01 \mathrm{~g} \mathrm{NH} \mathrm{H}_{2} \mathrm{OH} \cdot \mathrm{HCl}$ in a beaker containing a small amount of deionized water. The formed solution was then poured into a $100 \mathrm{~mL}$ measuring flask and diluted.

Ascorbic acid $\left(\mathrm{C}_{6} \mathrm{H}_{8} \mathrm{O}_{6}\right)$ solution was made by dissolving $0.01 \mathrm{~g}$ of $\mathrm{C}_{6} \mathrm{H}_{8} \mathrm{O}_{6}$ in a beaker with a small amount of deionized water. The formed solution was then put into a $100 \mathrm{~mL}$ measuring flask and diluted. The solid $\mathrm{Na}_{2} \mathrm{C}_{2} \mathrm{O}_{4}$ weighed to $0.05 \mathrm{~g}$, put into a $100 \mathrm{~mL}$ beaker and $50 \mathrm{~mL}$ deionized water added. The mixture was heated over hot plate at $60^{\circ} \mathrm{C}$ while stirring until the solid is completely dissolved. After that sodium oxalate solution was kept to cool and transferred into a $100 \mathrm{~mL}$ measuring flask. Finally, deionized water was added and dilute the solution to the measured mark and was shaken until becomes homogeneous solution.

For preparing the solution of $\mathrm{Na}_{2} \mathrm{SO}_{3}$, it was made by dissolving $0.1 \mathrm{~g} \mathrm{Na}_{2} \mathrm{SO}_{3}$ in a beaker containing a small amount of deionized water. The formed solution was further diluted to $100 \mathrm{~mL}$.

1,10-Phenanthroline solution was prepared by dissolving $0.1 \mathrm{~g}$ of 1.10 -phenanthroline into $100 \mathrm{~mL}$ beaker containing $50 \mathrm{~mL}$ deionized water. The mixture was heated to $60^{\circ} \mathrm{C}$ with stirring. Then the solution was allowed to cool and put into a $100 \mathrm{~mL}$ measuring flask and diluted with deionized water.

Acetate buffer solution: Buffer acetate solution $\mathrm{pH} 4.5$ was prepared by dissolving $1.31 \mathrm{~g}$ of sodium acetate in deionized water until dissolved. The acetate buffer solution $\mathrm{pH} 4.5$ was fed into $100 \mathrm{~mL}$ measuring flask and then $5 \mathrm{~mL}$ acetic acid diluted with deionized water. Furthermore, acetate buffer solution varied in $\mathrm{pH}(3.0 ; 3.5 ; 4.0 ; 4,5 ; 5.0)$.

Blank solution: The reducing agent $\mathrm{NH}_{2} \mathrm{OH} \cdot \mathrm{HCl}, \mathrm{Na}_{2} \mathrm{~S}_{2} \mathrm{O}_{3}$, $\mathrm{C}_{6} \mathrm{H}_{8} \mathrm{O}_{6}, \mathrm{Na}_{2} \mathrm{C}_{2} \mathrm{O}_{4}$ or $\mathrm{Na}_{2} \mathrm{SO}_{3}$ solution of 100 ppm was pipetted $1.1 \mathrm{~mL}$ and added into a $10 \mathrm{~mL}$ measuring flask with $1.5 \mathrm{~mL}$ 1,10-phenanthroline $1000 \mathrm{ppm}, 1.5 \mathrm{~mL}$ buffer acetate $\mathrm{pH} 4.5$ and $5 \mathrm{~mL}$ of acetone. Then, the solution was diluted with deionized water.

Wavelength determination: A standard solution of 100 ppm $\mathrm{Fe}(\mathrm{III})(0.5 \mathrm{~mL})$ was added into a $10 \mathrm{~mL}$ measuring flask, then added a reducing agent solution. Later, the mixture was added with $5 \mathrm{~mL}$ of acetone and diluted with deionized water. After that the solution was shaken and left for $15 \mathrm{~min}$ and measured using UV-VIS.

Determination of pH optimum: The treatment was almost the same as wavelength determination, only done by varying the pHs $(3.0 ; 3.5 ; 4.0 ; 4,5 ; 5.0 ; 5.5 ; 6.0)$. Then the mixture, $1.5 \mathrm{~mL}$ of 1,10 -phenanthroline (1000 ppm) and $5 \mathrm{~mL}$ of acetone, then diluted with deionized water. After that the solution was shaken and left for $15 \mathrm{~min}$ and measured its absorbance.

Determination of optimum time: A standard solution of $100 \mathrm{ppm} \mathrm{Fe}(\mathrm{III})(0.5 \mathrm{~mL})$ was added into a reducing agent solution. The mixture was added with $1.5 \mathrm{~mL}$ acetate buffer at optimum $\mathrm{pH}$. Afterward, the mixture was added with $1.5 \mathrm{~mL}$ 1,10-Phenantrolin $1000 \mathrm{ppm}$ and $5 \mathrm{~mL}$ of acetone then diluted with deionized water. The variation time for complex formation was measured at $0,15,30,45,60 \mathrm{~min}$.

Determination of optimum concentration: The treatment for determination of optimum reduction concentration was the same as the treatment of determination of $\mathrm{pH}$ optimum for reduction. But, the difference is the concentration of each reducing agent. Data variation concentration of reducing agents is shown in Table-1. After the treatment is carried out until the dilution stage with deionized water, then measured by UV-visible spectrometry.

TABLE-1

CONCENTRATION VARIATION OF REDUCING AGENTS

\begin{tabular}{ccccc}
\hline \multicolumn{5}{c}{ Variation concentration of reducing agent (ppm) } \\
\hline $\mathrm{Na}_{2} \mathrm{~S}_{2} \mathrm{O}_{3}$ & $\mathrm{NH}_{2} \mathrm{OH} \cdot \mathrm{HCl}$ & $\mathrm{C}_{6} \mathrm{H}_{8} \mathrm{O}_{6}$ & $\mathrm{Na}_{2} \mathrm{C}_{2} \mathrm{O}_{4}$ & $\mathrm{Na}_{2} \mathrm{SO}_{3}$ \\
\hline 5 & 5 & 3 & 10 & 40 \\
7 & 6 & 4 & 11 & 50 \\
9 & 7 & 5 & 12 & 60 \\
11 & 8 & 6 & 13 & 70 \\
13 & 9 & 7 & 14 & 80 \\
15 & 10 & 8 & 15 & - \\
- & 11 & 9 & - & - \\
- & 12 & - & - & - \\
\hline
\end{tabular}

\section{RESULTS AND DISCUSSION}

Determination of the maximum wavelength of $\mathrm{Fe}(\mathrm{II})-1,10$ phenanthroline can be seen from the highest absorbance value from the UV-vis spectrometry. In this study, $\mathrm{FeCl}_{3} \cdot 6 \mathrm{H}_{2} \mathrm{O}$ was used. First, $\mathrm{Fe}^{3+}$ solution was reduced to $\mathrm{Fe}^{2+}$ with five reducing agents, namely: sodium thiosulfate, hydroxylamine hydrochloride, ascorbic acid, sodium oxalate and sodium sulfite which were mixed with 1,10-phenanthroline solution at different $\mathrm{pHs}$ (4.0; 4.5 and 5.0) with a connection between $15-45 \mathrm{~min}$, then measured with a UV-visible spectrometry. The reaction of Fe(II) with reducing agents can be shown eqns. 1-5:

$$
\begin{aligned}
& 2 \mathrm{Fe}^{3+}{ }_{(\mathrm{aq})}+2 \mathrm{~S}_{2} \mathrm{O}_{3}{ }^{2-}{ }_{\text {(aq) }} \rightleftharpoons 2 \mathrm{Fe}^{2+}{ }_{(\mathrm{aq})}+\mathrm{S}_{4} \mathrm{O}_{6}{ }^{2-}{ }_{\text {(aq) }} \\
& 4 \mathrm{Fe}^{3+}{ }_{\text {(aq) }}+2 \mathrm{NH}_{2} \mathrm{OH} \cdot \mathrm{HCl}_{(\mathrm{aq})} \rightleftharpoons
\end{aligned}
$$

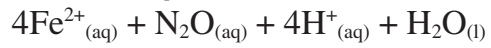

$$
\begin{aligned}
& 2 \mathrm{Fe}^{3+}{ }_{\text {(aq) }}+\mathrm{C}_{6} \mathrm{H}_{8} \mathrm{O}_{6 \text { (aq) }}+2 \mathrm{H}_{2} \mathrm{O}_{(\mathrm{l})} \rightleftharpoons \\
& 2 \mathrm{Fe}^{2+}{ }_{\text {(aq) }}+\mathrm{C}_{6} \mathrm{H}_{6} \mathrm{O}_{6(\text { aq })}+2 \mathrm{H}_{3} \mathrm{O}+{ }_{(\mathrm{aq})} \\
& 2 \mathrm{Fe}^{3+}{ }_{(\text {aq })}+\mathrm{C}_{2} \mathrm{O}_{4}{ }_{(\text {aq })}^{2-} \rightleftharpoons 2 \mathrm{Fe}^{2+}{ }_{(\text {aq })}+2 \mathrm{CO}_{2 \text { (aq) }} \\
& 2 \mathrm{Fe}^{3+}{ }_{(\mathrm{aq})}+\mathrm{SO}_{3}{ }^{2-}{ }_{(\mathrm{aq})}+\mathrm{H}_{2} \mathrm{O}_{(\mathrm{l})} \rightleftharpoons \\
& 2 \mathrm{Fe}^{2+}{ }_{(\text {aq })}+\mathrm{SO}_{4}{ }_{(\text {aq })}^{2-}+2 \mathrm{H}_{(\text {aq) }}^{+}
\end{aligned}
$$

The resulting wavelength is found to be $510 \mathrm{~nm}$ for five reducing agents (Fig. 1). The colour of complex Fe(II)-1,10phenanthroline solution is red orange, stable under acidic or alkaline conditions that are in the range of $\mathrm{pH} 2-9$, but for this study, it is carried out in an acidic media using an acetate buffer solution. Alkaline buffers are not selected because $\mathrm{OH}^{-}$ions are ligands that often compete with 1,10-phenanthroline ligands. To determine the effect of $\mathrm{pH}$ on the absorption of Fe(II). The results of optimum $\mathrm{pH}$ is shown in Table-2. 


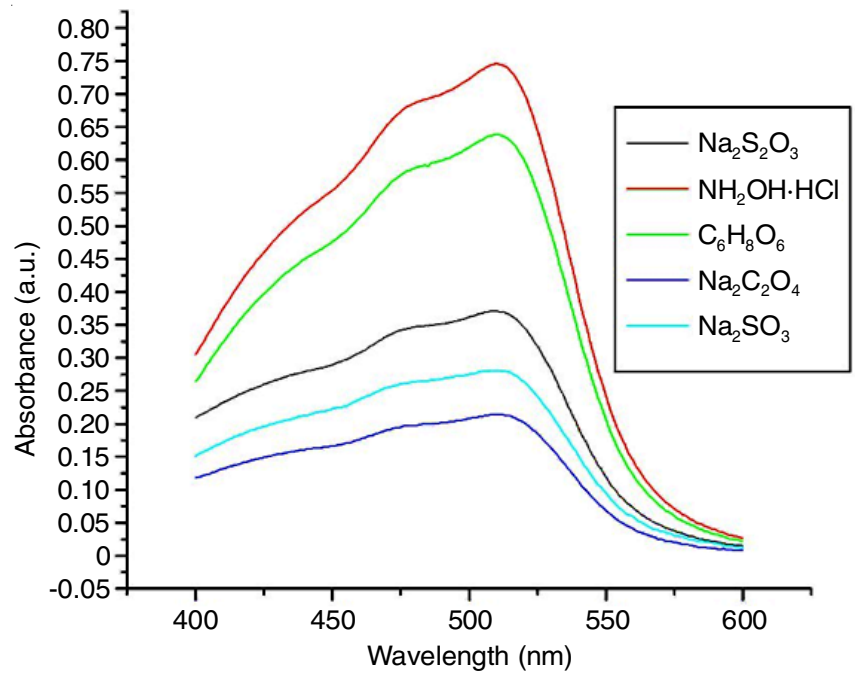

Fig. 1. Wavelength (nm) Fe(II)-phenanthroline with reducing agents

\begin{tabular}{ccc} 
TABLE-2 \\
OPTIMUM pH ACETATE BUFFER FOR REDUCING AGENTS \\
\hline Reducing agent & $\mathrm{pH}$ & Absorbance $(\mathrm{nm})$ \\
\hline $\mathrm{Na}_{2} \mathrm{~S}_{2} \mathrm{O}_{3}$ & 4.5 & 0.434 \\
$\mathrm{NH}_{2} \mathrm{OH} \cdot \mathrm{HCl}$ & 4.5 & 0.632 \\
$\mathrm{C}_{6} \mathrm{H}_{8} \mathrm{O}_{6}$ & 4.5 & 0.610 \\
$\mathrm{Na}_{2} \mathrm{C}_{2} \mathrm{O}_{4}$ & 5.0 & 0.268 \\
$\mathrm{Na}_{2} \mathrm{SO}_{3}$ & 4.0 & 0.280 \\
\hline
\end{tabular}
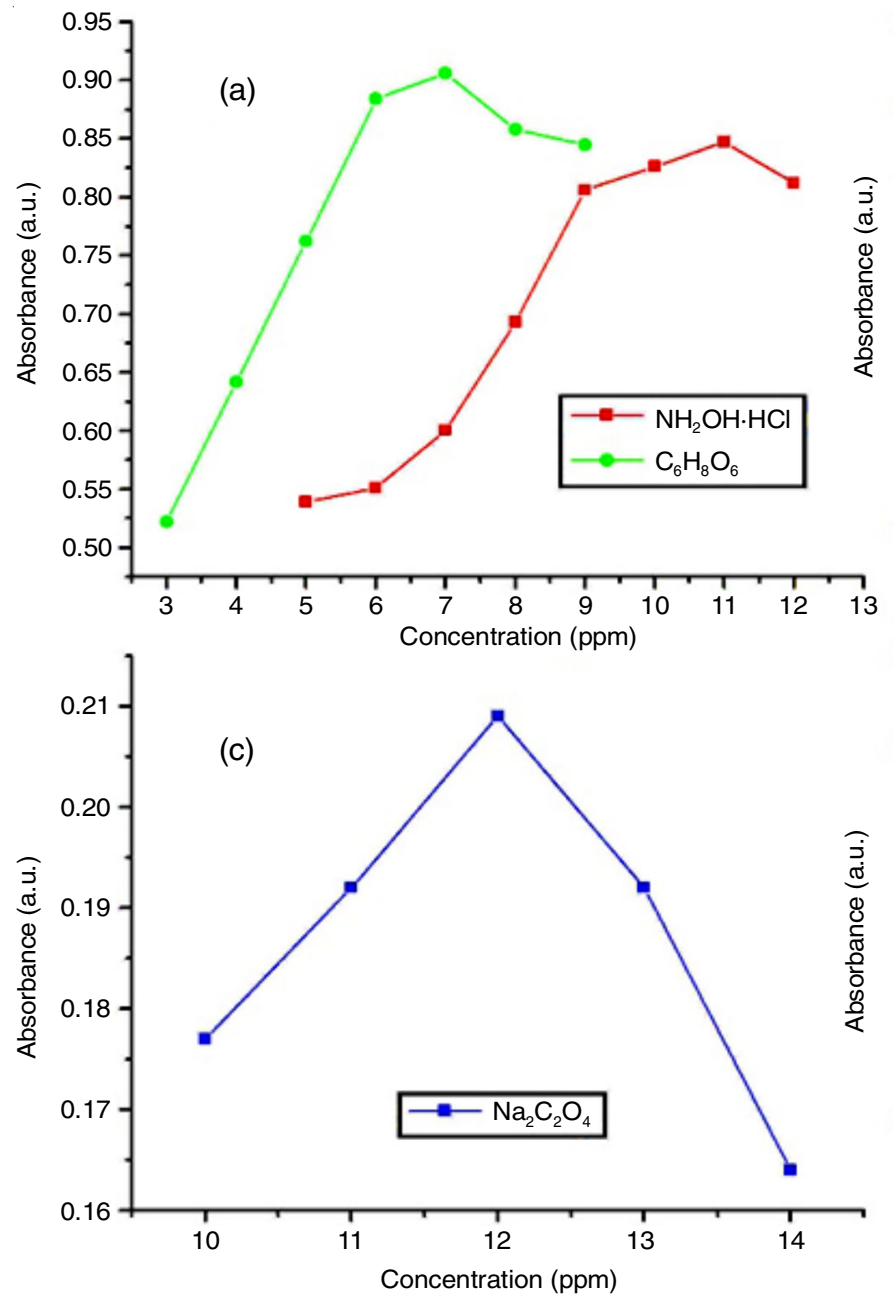

The reduction time is the formation of Fe(II)-1,10-phenanthroline complexes. All Fe ${ }^{2+}$ ions can bind 1,10-phenanthroline ligand and form complexes. To improve the performance of $\mathrm{Fe}(\mathrm{II})-1,10$-henanthroline, it is necessary to produce optimal time. A time variation was used to influence the time of reduction from 0 to $60 \mathrm{~min}$. The optimum time of determination of Fe(II)1,10-phenanthroline complex formation with each reducing agent was carried out at optimum $\mathrm{pH}$, respectively. The results of time optimum are shown in Table-3.

\begin{tabular}{ccc}
\multicolumn{4}{c}{ TABLE-3 } \\
OPTIMUM TIME FOR REDUCING AGENTS \\
\hline Reducing agent & Time (min) & Absorbance $(\mathrm{nm})$ \\
\hline $\mathrm{Na}_{2} \mathrm{~S}_{2} \mathrm{O}_{3}$ & 15 & 0.320 \\
$\mathrm{NH}_{2} \mathrm{OH} \cdot \mathrm{HCl}$ & 15 & 0.799 \\
$\mathrm{C}_{6} \mathrm{H}_{8} \mathrm{O}_{6}$ & 15 & 0.610 \\
$\mathrm{Na}_{2} \mathrm{C}_{2} \mathrm{O}_{4}$ & 45 & 0.268 \\
$\mathrm{Na}_{2} \mathrm{SO}_{3}$ & 30 & 0.406 \\
\hline
\end{tabular}

Determination of optimum concentration the reducing agent aims to decide at what concentration to be for reduce $\mathrm{Fe}^{3+}$ ion to $\mathrm{Fe}^{2+}$ ion with complexing 1,10-phenanthroline at an acidic atmosphere. The results of concentration optimum are shown in Table-4. Based on Fig. 2a, the peak of optimum concentration reducing agents $\mathrm{NH}_{2} \mathrm{OH} \cdot \mathrm{HCl}$ is $11 \mathrm{ppm}$ and $\mathrm{C}_{6} \mathrm{H}_{8} \mathrm{O}_{6}$ is $7 \mathrm{ppm}$. But the peak was out of Lambert-Beer range
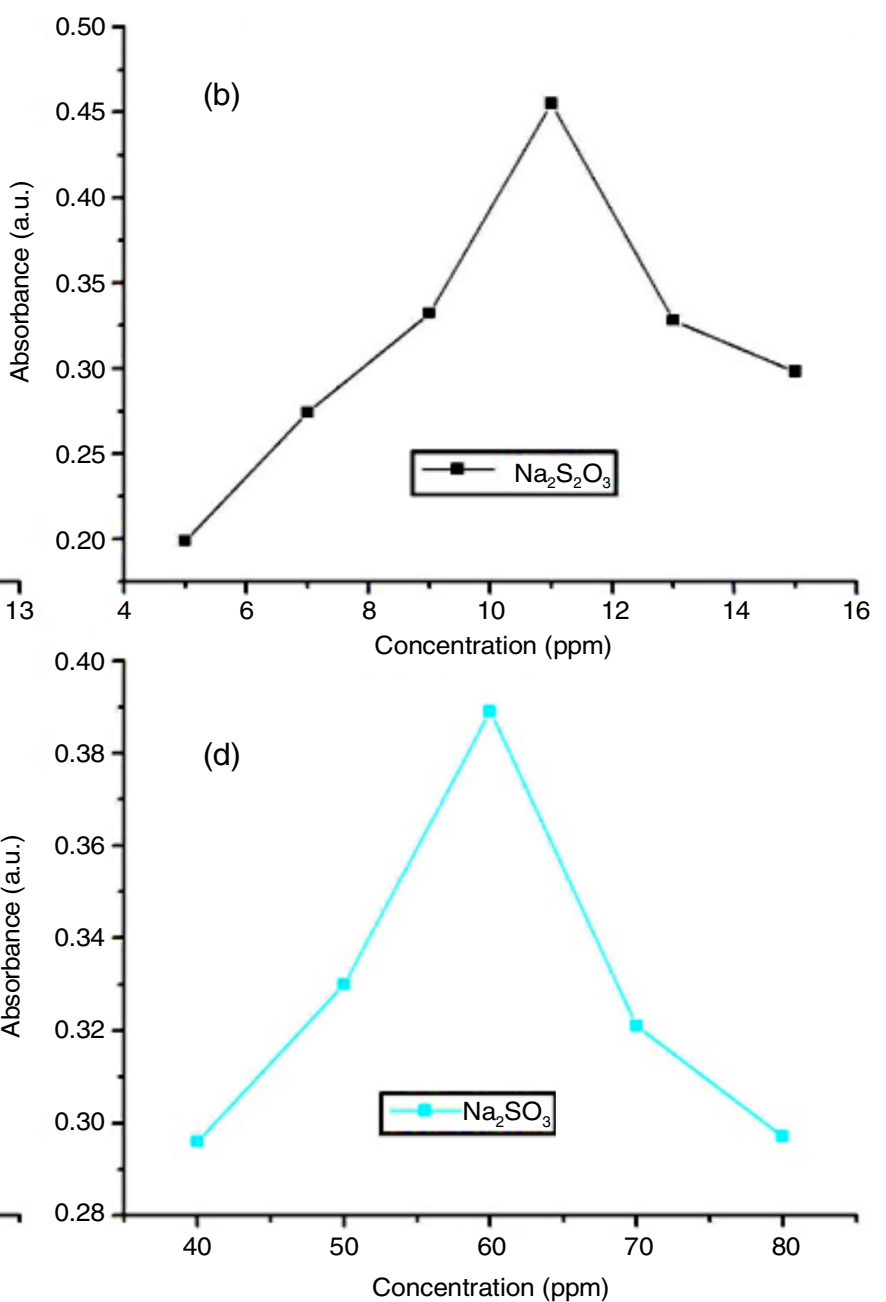

Fig. 2. Optimum curve concentration Fe(II)-phenanthroline with reducing agents 


\begin{tabular}{ccc}
\hline \multicolumn{3}{c}{ TABLE-4 } \\
\multicolumn{3}{c}{ OPTIMUM REDUCING AGENTS CONCENTRATION } \\
\hline Reducing agent & Concentration (ppm) & Absorbance (nm) \\
\hline $\mathrm{Na}_{2} \mathrm{~S}_{2} \mathrm{O}_{3}$ & 11 & 0.455 \\
$\mathrm{NH}_{2} \mathrm{OH} \cdot \mathrm{HCl}$ & 8 & 0.693 \\
$\mathrm{C}_{6} \mathrm{H}_{8} \mathrm{O}_{6}$ & 5 & 0.762 \\
$\mathrm{Na}_{2} \mathrm{C}_{2} \mathrm{O}_{4}$ & 12 & 0.209 \\
$\mathrm{Na}_{2} \mathrm{SO}_{3}$ & 60 & 0.389 \\
\hline
\end{tabular}

(0.2-0.8). So, to comply with the regulation, the concentration of $\mathrm{NH}_{2} \mathrm{OH} \cdot \mathrm{HCl}$ was adjusted to $8 \mathrm{ppm}$ with absorbance 0.693 and $\mathrm{C}_{6} \mathrm{H}_{8} \mathrm{O}_{6}$ was adjusted to $5 \mathrm{ppm}$ with absorbance 0.762 .

In this work, the value of percentage recovery was obtained from five reducing agents at optimum conditions $(\mathrm{pH}$, time, and concentration). In this study, it can be stated that this data is good and can be used for further measurement because it is in the range of 80-100\% with accuracy level is $95 \%$ (Table-5).

\begin{tabular}{cc}
\multicolumn{2}{c}{ TABLE-5 } \\
RECOVERY (\%) OF REDUCING AGENTS \\
\hline Reductors & Recovery (\%) \\
\hline $\mathrm{Na}_{2} \mathrm{~S}_{2} \mathrm{O}_{3}$ & 103.440 \\
$\mathrm{NH}_{2} \mathrm{OH} \cdot \mathrm{HCl}$ & 116.007 \\
$\mathrm{C}_{6} \mathrm{H}_{8} \mathrm{O}_{6}$ & 98.068 \\
$\mathrm{Na}_{2} \mathrm{C}_{2} \mathrm{O}_{4}$ & 85.886 \\
$\mathrm{Na}_{2} \mathrm{SO}_{3}$ & 84.590 \\
\hline
\end{tabular}

\section{Conclusion}

Based on the results of this study, it is concluded that the best reducing agent for reducing iron(III) to iron (II) using UV-visible spectrometry with maximum wavelength $510 \mathrm{~nm}$ is hydroxylamine hydrochloride $\left(\mathrm{NH}_{2} \mathrm{OH} \cdot \mathrm{HCl}\right)$ with optimum $\mathrm{pH}$ at $\mathrm{pH} 4.5$, optimum time for $15 \mathrm{~min}$ at a concentration of 8 ppm. The second best reducing agent is ascorbic acid $\left(\mathrm{C}_{6} \mathrm{H}_{8} \mathrm{O}_{6}\right)$ with optimum $\mathrm{pH}$ at $\mathrm{pH} 4,5$, optimum time for $15 \mathrm{~min}$ at a concentration of $5 \mathrm{ppm}$. The recovery percentage for different reducing agents were found to be as $87.68 \%$ (for $\mathrm{Na}_{2} \mathrm{~S}_{2} \mathrm{O}_{3}$ ), $116.00 \%$ (for $\mathrm{NH}_{2} \mathrm{OH} \cdot \mathrm{HCl}$ ), $98.068 \%$ (for $\mathrm{C}_{6} \mathrm{H}_{8} \mathrm{O}_{6}$ ), $85.97 \%$ (for $\mathrm{Na}_{2} \mathrm{C}_{2} \mathrm{O}_{4}$ ) and $103.44 \%$ (for $\mathrm{Na}_{2} \mathrm{SO}_{3}$ ).

\section{CONFLICT OF INTEREST}

The authors declare that there is no conflict of interests regarding the publication of this article.

\section{REFERENCES}

1. A. Fisiana, Final Project, Departement of Chemistry, Faculty of Science, Institut Teknologi Sepuluh Nopember, Indonesia (2012).

2. E. Pehlivan and D. Kara, Mikrochim. Acta, 158, 137 (2007); https://doi.org/10.1007/s00604-006-0697-4.

3. S. Roncevic and I. Steffan, At. Spectrosc., 25, 125 (2004).

4. M. Grotti, F. Soggia, F. Ardini and R. Frache, J. Anal. At. Spectrom., 24, 522 (2009); https://doi.org/10.1039/b818236a.

5. C. Xiong, Z. Jiang and B. Hu, Anal. Chim. Acta, 559, 113 (2006); https://doi.org/10.1016/j.aca.2005.11.051.

6. A. Abbaspour, M.A. Mehrgardi, A. Noori, M.A. Kamyabi, A. Khalafi-Nezhad and M.N. Soltani Rad, Sens. Actuators B: Chem., 113, 857 (2006); https://doi.org/10.1016/j.snb.2005.03.119.

7. O. Mikkelsen, C. Van Den Berg and K. Schroder, Electroanalysis, 18, 35 (2006); https://doi.org/10.1002/elan.200503360.

8. A. Itodo, U. Abdullahi, B. Saliha and U. Happiness, Adv. Anal. Chem., 1, 16 (2012)

9. T. An, N. Lee, H.-J. Cho, S. Kim, D.-S. Shin and S.-M. Lee, RSC Adv., 7, 30582 (2017) https://doi.org/10.1039/c7ra04107a

10. A.S. Amin and A.A. Gouda, Talanta, 76, 1241 (2008); https://doi.org/10.1016/j.talanta.2008.05.034.

11. Amelia, Final Project, Department of Chemistry, Faculty of Science, Institut Teknologi Sepuluh Nopember, Indonesia (2004).

12. H. Radityo, Final Project, Department of Chemistry, Faculty of Science, Institut Teknologi Sepuluh Nopember, Indonesia (2004). 